\title{
Cladonia uncialis as a valuable raw material of biosynthetic compounds against clinical strains of bacteria and fungi*
}

\author{
Elżbieta Studzińska-Sroka1凶, Hanna Tomczak2,3, Natalia Malińska², Marta Wrońska², \\ Robert Kleszcz ${ }^{4}$ Agnieszka Galanty5, Judyta Cielecka-Piontek', Dorota Latek ${ }^{6}$ and \\ Jarosław Paluszczak4
}

\begin{abstract}
'Department of Pharmacognosy, Poznan University of Medical Sciences, Poznań, Poland; ${ }^{2}$ Central Microbiological Laboratory, Święcicki University Hospital, Poznań, Poland; ${ }^{3}$ Department of Dermatology and Venereology, Poznan University of Medical Sciences, Poznań, Poland; ${ }^{4}$ Department of Pharmaceutical Biochemistry, Poznan University of Medical Sciences, Poznań, Poland; ${ }^{5}$ Department of Pharmacognosy, Jagiellonian University Medical College, Kraków, Poland; ${ }^{6}$ Faculty of Chemistry, University of Warsaw, Warsaw, Poland
\end{abstract}

\begin{abstract}
Cladonia uncialis is a lichen species with confirmed antibacterial activity and whose genome has been recently sequenced, enabling first attempts in its functional characterization. In this work, we investigated activity of the C. uncialis acetone extract (CUE) and usnic acid (UA) enantiomers against ten clinical microbial strains causing skin infections. The results showed that CUE, containing (-)-UA and squamatic acid, assayed at the same concentrations as UA, was noticeably more active than (-)-UA alone, in its pure form. The studied CUE displayed an activity that was comparable to that of (+)-UA observed for Staphylococcus epidermidis and Enterococcus faecium (18-24 mm zone of growth inhibition), but did not display any activity against fungal strains. The CUE demonstrated low cytotoxicity against HaCaT cells, in comparison to UA enantiomers, which is important for its therapeutic use. Results of the antioxidant assay (DPPH) indicated low antioxidant activity $\left(\mathrm{IC}_{50}>200 \mu \mathrm{g} / \mathrm{mL}\right)$ of CUE, while the total phenolic content was $70.36 \mathrm{mg} \mathrm{Gal}-$ lic Acid Equivalent/g of the dry extract.
\end{abstract}

Key words: lichen metabolites, lichen extract, antibacterial activity, cytotoxicity, $\mathrm{HaCaT}$, antioxidant activity

Received: 20 October, 2019; revised: 20 November, 2019; accepted: 22 November, 2019; available on-line: 15 December, 2019

⿶e-mail: ela_studzinska@op.pl

*Acknowledgements of Financial Support:

The costs of the article published as a part of the 44th FEBS Congress Kraków 2019 - From molecules to living systems block are financed by the Ministry of Science and Higher Education of the Republic of Poland (Contract 805/P-DUN/2019).

Abbreviations: DMEM, dulbecco's modified eagle medium; BHA, butylated hydroxyanisole; GAE, gallic acid equivalent; HPLC, highperformance liquid chromatography; MS, mass spectrometry; NMR, nuclear magnetic resonance; TMS, tetramethylsilane; TPC, total phenolic content

\section{INTRODUCTION}

Lichen species produce a wide range of secondary metabolites to increase their survival fitness under extreme conditions. Numerous studies had shown that lichen micro-ecosystems produce substances that demonstrate multidirectional biological activity and thus could be used in pharmacology (Lücking et al., 2016). About $50 \%$ (Candan et al., 2007) of all 19000 lichen species known to date (Abdel-Hammed et al., 2016) contain antibacterial substances that could be used against antibiotic-resistant bacterial strains in treatment of wounds, skin infections, and upper respiratory and gastrointestinal symptoms. The most known lichenic compound is usnic acid (UA), existing in two enantiomeric forms of which (+)-UA occurs more frequently (Cetin et al., 2008). Results of research carried out so far indicate a high antibacterial activity of UA, mainly against Gram-positive strains (Galanty et al., 2019). Most of studies on antibacterial activity of UA were focused on its $(+)$ enantiomer, which usually demonstrated an increased activity in comparison to its (-) form (Galanty et al., 2012). In addition to antibacterial properties, UA has also antioxidant, antiproliferative, antiprotozoal, larvicidal and insecticidal, antifungal, antiviral, algicidal, anti-inflammatory, pain-relieving and antipyretic properties, as has been demonstrated by in vivo and in vitro studies (Alahmadi, 2017).

Cladonia uncialis L. Weber ex F.H. Wigg., (order Lecanorales, family Cladoniaceae), is a fruticose lichen, growing on humus or sandy soil, mainly in pinewood forests, on moors, dunes or roadside. This species is found on all continents except Antarctica, especially in the Northern Hemisphere. In Poland, it is common throughout the country (Purvis et al., 1992; Wójciak, 2007). C. uncialis is known for its biosynthesis of (-)-UA, hardly observed in other lichen species (Abdel-Hameed et al., 2016). Recently, the $C$. uncialis genome has been sequenced, which allowed for its functional genomic analysis (Bertrand et al., 2018a). A number of biologically active secondary metabolites have been characterized via a homology mapping approach (Bertrand et al., 2018a; Bertrand et al., 2018b), including the well-studied aromatic polyketides (Bertrand et al., 2019). Nevertheless, functional analysis of C. uncialis and other lichens involving heterologous expression or gene knockout experiments is still challenging due to their slow rate of growth, obligated symbioses and other difficulties in establishing their cultures (Grube et al., 2014; Bertrand et al., 2019; Cimmino et al., 2019). What is more, differences in cultivation conditions have impact on the extract composition (Bjerke et al., 2005; Brisdelli et al., 2013; Studzińska-Sroka et al., 2015). Consequently, there is still a noticeable disproportion between known biosynthetic gene clusters and characterized secondary metabolites of C. uncialis and other lichens (Bertrand et al., 2018a). To date, the genome sequencing of $C$. uncialis has revealed (Bertrand et al., 2018a) presence of 48 biosynthetic gene clusters, including: type I and III polyketide synthases (PKS), nonribosomal peptide synthetases (NRPS), hybrid PKS-NRPS and a terpene synthase. The $C$. uncialis genome was proposed to include enzymes for grayanic acid, patulin and betaenone biosynthesis, and the latter 
two were not found in other lichen species (Bertrand et al., 2018b). A recent genome mining study of other lichen species, Evernia prunastri and Pseudevernia furfuracea, reported 80 biosynthetic gene clusters in the first one and 51 in the latter (Calchera et al., 2019) that also included polyketide synthases, non-ribosomal peptide synthetases and terpene synthases.

The thallus of $C$. uncialis contains (-)-UA, as well as squamatic and thamnolic acids (Purvis et al., 1992), but the biological activity of its extracts is almost unknown. The antibacterial activity of $C$. uncialis extracts has been proven for the first time in our previous studies, in which we demonstrated a high activity of the $C$. uncialis acetone extract (CUE) on methicillin-resistant Staphylococcus aureus (MRSA) strains (Studzińska-Sroka et al., 2015). These interesting findings, as well as previous information about antimicrobial activity of UA (Galanty et al., 2012; Alahmadi et al., 2017; Galanty et al., 2019), prompted us to expand the study on the activity of CUE against clinical pathogenic strains responsible for skin and wound infections, which demonstrate resistance to antibiotics. In our research we also compared the cytotoxic effect of the tested substances by employing in vitro studies with human keratinocyte cell cultures (HaCaT). Although the cytotoxic properties of (+)-UA on HaCaT cells were previously studied, the respective research involving CUE and (-)-UA has not been conducted yet (Brisdelli et al., 2013). We determined the CUE composition using NMR and MS, while the quantity of (-)-UA in CUE was determined with HPLC. The content of polyphenols (TPC) was evaluated with the Folin-Ciocalteu (FC) analysis. The antioxidant activity of (-)-UA and CUE was also investigated.

\section{MATERIALS AND METHODS}

Plant material. The C. uncialis (L.) Weber ex F.H. Wigg. lichen was manually collected in September 2014 in Jastrzębsko Stare, Poland, and authenticated by $\mathrm{dr}$ Daria Zarabska-Bożejewicz (The Institute for Agricultural and Forest Environment of Polish Academy of Sciences in Poznan). A voucher specimen (ES 2014.007) has been deposited in the herbarium of the Department of Pharmacognosy at Poznan University of Medical Sciences.

General. Acetone, dimethylsulphoxide (DMSO), methanol, sodium carbonate and HPLC grade: water, chloroform and methanol, were purchased from POCH, Gliwice, Poland; HPLC grade: $85 \%$ phosphoric acid, 2,2-diphenyl-1-picrylhydrazyl (DPPH), and the reference compounds: gallic acid, vitamin $\mathrm{C}$ and BHA were from Sigma Aldrich, USA. Folin-Ciocalteu's phenol reagent, was from Merck, Germany; Usnic acids: (-)-usnic acid and (+)-usnic acid came from the compounds' collection of the Pharmacognosy Department (their identity, optical rotation and purity were assessed by: UV, ${ }^{1} \mathrm{H}$ NMR, ${ }^{13} \mathrm{C}$ NMR, MS, and polarimetric analysis).

Preparation of extracts. Air-dried and coarsely ground lichen thalli $(19 \mathrm{~g})$ were extracted four times with $200 \mathrm{~mL}$ of acetone $(800 \mathrm{~mL}$ total) in a ultrasonic bath (Elmasonic S $180 \mathrm{H}$, Elma, Germany) at $30-35{ }^{\circ} \mathrm{C}$ for $30 \mathrm{~min}$. The extracts were filtered using Whatman filter paper No. 1 and then evaporated under reduced pressure at $35^{\circ} \mathrm{C}$, yielding $201.4 \mathrm{mg}$ of solid residue.

Determination of the total phenolic content. TPC was determined using the Folin-Ciocalteu method described by Gawron-Gzella and others (Gawron-Gzella et al., 2016), with modifications. Briefly, $0.1 \mathrm{~mL}$ of CUE dissolved in DMSO $(10 \mathrm{mg} / \mathrm{mL})$ was mixed with $7.4 \mathrm{~mL}$ of distilled water and with $0.5 \mathrm{~mL}$ of the Folin-Ciocalteu reagent. The mixture was shaken vigorously and $2.0 \mathrm{~mL}$ of $20 \%(\mathrm{w} / \mathrm{v})$ sodium carbonate solution was added after $1 \mathrm{~min}$. Next, the samples were incubated for $30 \mathrm{~min}$ in the dark, at room temperature. The absorbance was measured at $760 \mathrm{~nm}$ (UV/VIS Lambda 35 PerkinElmer). Total polyphenol concentration was calculated using gallic acid (0.02-0.08 mg/10 mL of sample) as a standard for a calibration curve $\left(y=0.1016 x-0.0029, R^{2}=0.9993\right)$. Total concentration of phenolic compounds in the extract was expressed as $\mathrm{mg}$ of gallic acid equivalent/g of the dry extract. The values are expressed as the mean of six replications \pm S.D.

Quantification of (-)-usnic acid in the extract. The quantity of (-)-UA in $C$. uncialis acetone extract (CUE) was examined by HPLC as described previously (Studzińska-Sroka et al., 2015), with water and 1\% 0.1N $\mathrm{H}_{3} \mathrm{PO}_{4}(\mathrm{v} / \mathrm{v})$ (A) and methanol (B), A:B 15:85 as the mobile phase. Detection was carried out with a PDA detector set at $250 \mathrm{~nm}$. To prepare the stock solution, $5.0 \mathrm{mg}$ of (-)-UA was dissolved in $5.0 \mathrm{~mL}$ of chloroform. In order to obtain calibration curves, appropriate volumes of the stock solution were transferred to volumetric flasks and diluted with the same solvent to give standard solutions of the following concentrations: $1.0,0.5,0.25,0.125$, and $0.0625 \mathrm{mg} / \mathrm{mL}(y=963.73 x-$ 16.051; $\left.\mathrm{R}^{2}=0.9986\right)$. Each concentration was analysed in triplicate under conditions described above. In order to analyse the samples, $5.0 \mathrm{mg}$ of the tested extract was dissolved in $5.0 \mathrm{~mL}$ of chloroform. The results were reported as the arithmetic mean \pm S.D. for three replications.

NMR and MS analyses of the crude extract. Identification of main compounds in CUE was carried out by NMR $(700 \mathrm{MHz}$ NMR spectrometer Bruker Avance III). Spectra were recorded after dissolving the substance in acetone- $\mathrm{d}_{6}$ and over TMS. ESI-MS data were acquired with Waters Maldi Q-Tof Premier mass spectrometer.

Determination of antibacterial activity. In this study, strains mostly responsible for skin infections were employed: clinical strains of Gram-positive bacteria staphylococci (Staphylococcus aureus, Staphylococcus epidermidis and Staphylococcus haemolyticcus), enterococci (Enterococcus faecalis and Enterococcus faecium), streptococci (Streptococcus pyogenes), Gram-negative bacilli (Escherichia coli and Pseudomonas aeruginosa), and yeast-like fungi (Candida albicans and Candida glabrata). The isolated strains were tested for their antibiotic sensitivity and the following culture media were used: Mueller Hinton Agar (OXOID), Mueller Hinton Agar with horse blood (OXOID) for bacterial strains, and RPMI agar (BioMaxima) for yeast-like fungi. Disc diffusion method was used to determine the antimicrobial activity, and therefore the results were expressed as the diameter of the zone of growth inhibition of the tested microorganisms by the tested substances. For the antimicrobial study, solutions of the acetone extract, as well as (-)-UA and (+)-UA in DMSO, were prepared $(10 \mathrm{mg} / \mathrm{mL})$. Blank sterile discs $(\varnothing=6 \mathrm{~mm}$; OXOID) were placed with slight pressure on inoculated media and impregnated with $10 \mu \mathrm{L}$ of the tested substances to obtain a content of $100 \mu \mathrm{g}$ of the extract or usnic acids in the disc. The Petri Dishes were incubated for $24 \mathrm{~h}$ for bacteria and $48 \mathrm{~h}$ for fungi, and the zone of inhibition was measured. Standard antibiotics' dishes for the tested microorganisms for Gram-positive bacteria (penicillin, amoxicillin/clavulanic acid, vancomycin, erythromycin, and clindamycin), to compare the inhibition zones around the antibiotic disc, were used as positive con- 
trols. DMSO solution was used as the negative control of the influence of the solvents. The inoculum density of 0.5 on McFarland scale was used for the disk diffusion method. All of the experiments were performed in triplicates and the antibacterial activity was expressed as the mean values.

Viability assay. Spontaneously immortalized $\mathrm{HaCa} \mathrm{T}$ keratinocytes (Cell Lines Service, Germany) were grown in a high-glucose DMEM medium (Biowest, France), supplemented with 10\% FBS (EURx, Poland), and 1\% antibiotics solution (penicillin and streptomycin, Biowest, France), in a humidified incubator in the atmosphere of $5 \% \mathrm{CO}_{2}$. Stock solutions of the dry extract, (-)-UA and $(+)-U A$ samples were prepared in DMSO. The effect of the solutions on the viability of $\mathrm{HaCaT}$ cells was assessed by using the MTT assay. Cells were seeded $\left(2 \times 10^{4}\right.$ cells/well) in a 96-well plate and preincubated for $\sim 24 \mathrm{~h}$. Next, fresh medium containing varying concentrations of the tested substances $(1-50 \mu \mathrm{g} / \mathrm{mL})$ was added into the wells and the cells were incubated for subsequent $72 \mathrm{~h}$. Afterwards, the cells were washed with PBS buffer and a fresh complete medium containing $0.5 \mathrm{mg} / \mathrm{mL}$ of MTT salt (Sigma, USA) was added. After a 4-hour incubation, formazan crystals were dissolved in acidic isopropanol and the absorbance was measured at $570 \mathrm{~nm}$ and $690 \mathrm{~nm}$. The assay was repeated three times with five measurements per assay. The results were calculated as percentage viability compared to control cells only treated with the vehicle.

DPPH assay. The free radical scavenging capacity of the acetone extract from C. uncialis was determined using the DPPH method described by Annegowda et al. (2010). Briefly, $0.1 \mathrm{~mL}$ of CUE, (-)-UA or (+)-UA, dissolved in DMSO $(6.0-0.1875 \mathrm{mg} / \mathrm{mL})$ was added to 2.9 $\mathrm{mL}$ of DPPH solution $(0.1 \mathrm{mM}$ in methanol; the final assay concentrations were $200.0-6.25 \mu \mathrm{g} / \mathrm{mL})$. The reaction mixture was shaken and incubated in the dark at room temperature for $30 \mathrm{~min}$. Absorbance was measured at $517 \mathrm{~nm}$ against a blank $(2.9 \mathrm{~mL}$ of methanol + $0.1 \mathrm{~mL}$ of DMSO) (UV/VIS Lambda 35 PerkinElmer). The control was a mixture of $2.9 \mathrm{~mL}$ of DPPH solution and $0.1 \mathrm{~mL}$ of DMSO. Vitamin $\mathrm{C}$ and BHA were used as the referring substances. The following equation was used to calculate concentration of the DPPH radicals:

DPPH scavenging activity $(\%)=\left(A_{0}-A_{1}\right) / A_{0} \times 100 \%$

where $A_{0}$ is the absorbance of the control and $A_{1}$ is the absorbance of the reaction mixture or standards. The $\mathrm{IC}_{50}$ values were calculated as the concentration required to inhibit $50 \%$ of DPPH radical. The values have been expressed as the mean of six replications.

Homology modelling of $C$. uncialis polyketide synthase. A homology model of $C$. uncialis non-reducing polyketide synthase was constructed using the $C$. nicotianae crystal structure (Herbst et al., 2018) (PDB id: 6FIJ), comprising of three domains: SAT, KS and MAT. This template, of the highest sequence overlap with the target, was selected by BLAST (Madden et al., 1996) from PDB (Evalue equal to $3 \mathrm{e}-104$, sequence identity $26.53 \%$ and sequence coverage 46\%). Only the KS domain model of the polyketide synthase (Fig. 1) was constructed using the BLAST-derived sequence alignment, MODELLER (Webb et al., 2016), and a previously developed procedure (Latek, 2017).

Statistical analysis. Statistical analyses were performed using GraphPad Prism version 5.00 for Windows (GraphPad Software, San Diego, CA) and Microsoft Excel 2013 software (Microsoft, Redmond, WA). The me-

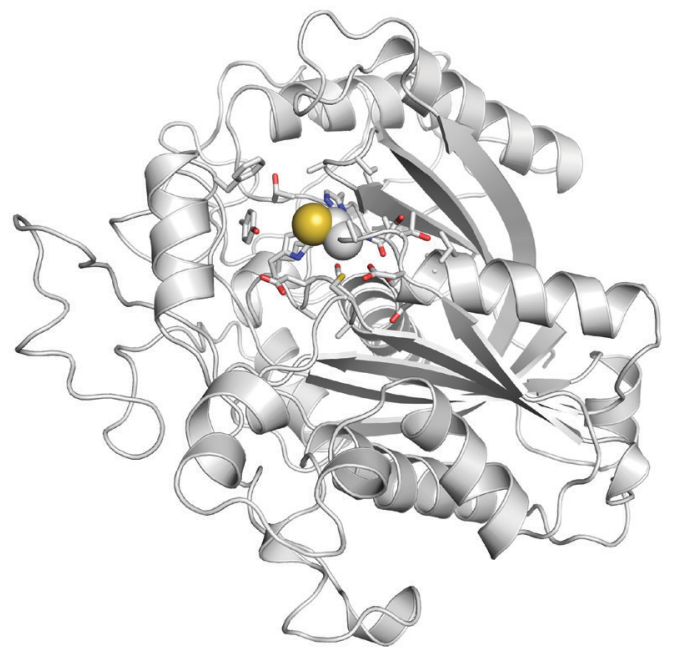

Figure 1. The central KS domain of the loading/condensing region (SAT-KS-MAT) of $C$. uncialis polyketide synthase.

The active site is depicted with Cys547 shown with spheres and other residues are shown with a balls and sticks representation.

dian effect concentrations $\left(\mathrm{IC}_{50}\right.$ values) were determined using a concentration-response curve.

\section{RESULTS AND DISCUSSION}

\section{Phytochemical characterisation of the extract}

Chemical composition of CUE (201.4 mg, yield $1.06 \%$ ), examined by ${ }^{1} \mathrm{H}$ NMR and MS, confirmed that its main compounds were UA and squamatic acid (result presented in Fig. 2). Presence of thamnolic acid described in the $C$. uncialis thallus was not confirmed with sufficient certainty using the applied procedure. The content of $(-)-\mathrm{UA}(52.52 \% \pm 0.28)$, in the extract analysed by HPLC, was higher than in our previous study (28.40\%) (Studzińśka-Sroka et al., 2015). This difference, as well as the lack of thamnolic acid in the studied extract, could result from various atmospheric conditions during the vegetation period of the lichen (Bjerke et al., 2005; Millot el al., 2007; Neupane et al., 2017). The results of FC analysis showed TPC equal to $70.36 \pm 1.42$ $\mathrm{mg} \mathrm{GAE} / \mathrm{g}$ of the dry extract, which is in accordance with data on TPC in other Cladonia species (Mitrović et al., 2011).

\section{Antimicrobial activity}

The emerging problem of bacterial resistance to existing antibiotics prompted research of new antibacterial agents that were derived from natural substances. Our study was aimed at evaluating the antimicrobial activity of CUE and UA enantiomers against eight clinical bacterial and two fungal strains, mainly responsible for skin infections and post-operative wounds. The obtained results demonstrated an increased activity of the tested substances against selected Gram-positive microorganisms, with no impact on Gram-negative strains (Table 1). The highest growth inhibitory zone (GIZ) was obtained for coagulase-negative staphylococci (CNS) (S. epidermidis, S. haemolyticus) and enterococci (E. faecalis, E. faecium). S. aureus and $S$. pyogenes were also affected, but to a lesser extent. In the case of enterococci and CNS (S. epidermidis, S. haemolyticus), GIZ was almost the same between (+)UA and CUE, but smaller for (-)-UA. For $S$. aureus, no 
A

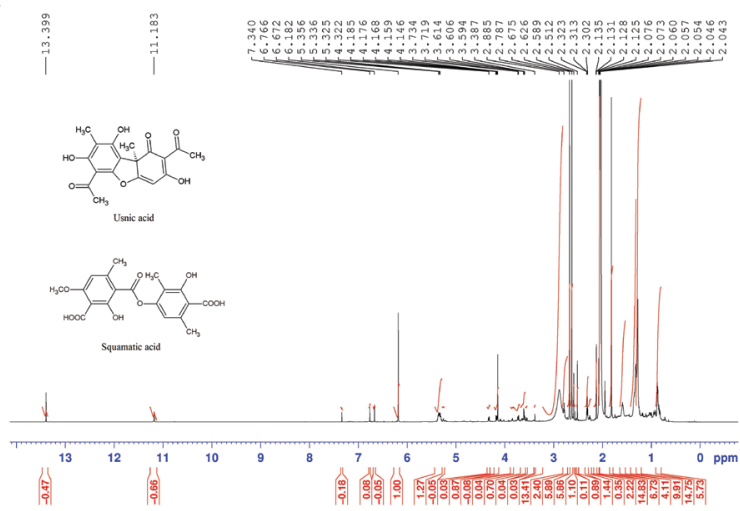

C

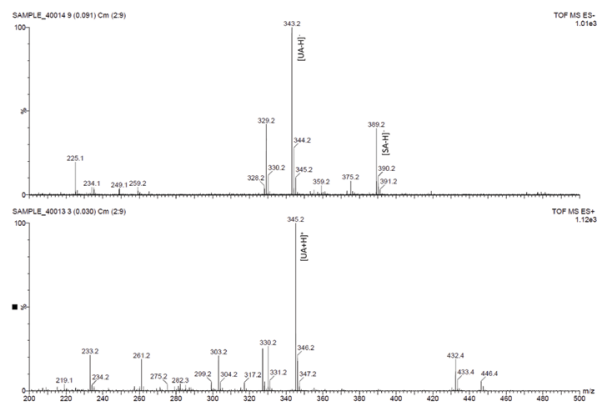

B

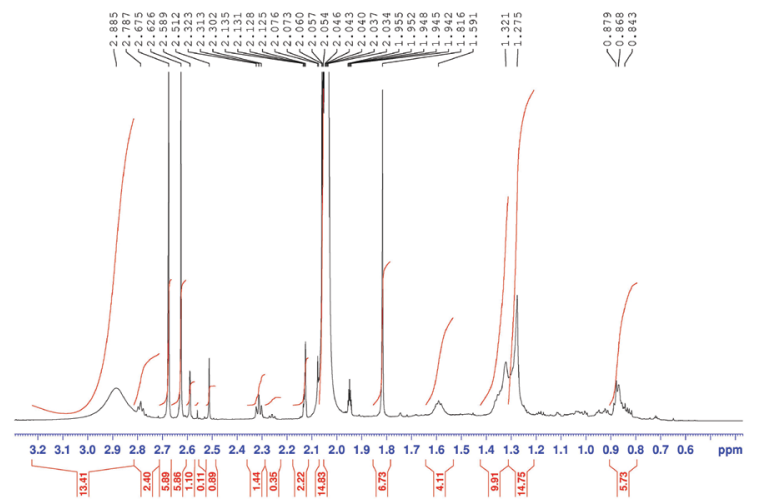

D

\begin{tabular}{|c|c|c|c|c|c|c|c|}
\hline \multirow[b]{2}{*}{ Compound } & \multicolumn{4}{|c|}{${ }^{\prime} \mathrm{H}$ NMR $\delta$ [ppm] } & \multicolumn{3}{|c|}{ MS } \\
\hline & $\begin{array}{l}\text { methyl } \\
\text { groups }\end{array}$ & $\begin{array}{l}\text { methylene } \\
\text { groups }\end{array}$ & $\begin{array}{l}\text { aromatic } \\
\text { hydrogens }\end{array}$ & $\begin{array}{l}\text { hydroxyl } \\
\text { groups }\end{array}$ & 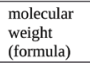 & $\begin{array}{l}\mathrm{m} / \mathrm{z} \\
\text { negative } \\
\text { mode }\end{array}$ & $\begin{array}{l}\mathrm{m} / \mathrm{z} \\
\text { positive } \\
\text { mode }\end{array}$ \\
\hline Usnic acid & $\begin{array}{l}1.82 \\
2.14 \\
2.63 \\
2.68\end{array}$ & - & 6.18 & $\begin{array}{l}11.18 \\
13.40\end{array}$ & $\begin{array}{l}344 \\
\left(\mathrm{C}_{18} \mathrm{H}_{10} \mathrm{O}_{7}\right)\end{array}$ & $\begin{array}{l}343.2 \\
{[\mathrm{M}-\mathrm{H}]}\end{array}$ & $\begin{array}{l}345.2 \\
{[\mathrm{M}+\mathrm{H}]^{+}}\end{array}$ \\
\hline $\begin{array}{l}\text { Squamatic } \\
\text { acid }\end{array}$ & $\begin{array}{l}2.51 \\
2.59\end{array}$ & 4.15 & $\begin{array}{l}6.67 \\
6.77\end{array}$ & - & $\begin{array}{l}390 \\
\left(\mathrm{C}_{19} \mathrm{H}_{18} \mathrm{O}_{9}\right)\end{array}$ & $\begin{array}{l}389.2 \\
{[\mathrm{M}-\mathrm{H}]}\end{array}$ & - \\
\hline
\end{tabular}

Figure 2. ' $\mathrm{H}$ NMR and MS analysis of Cladonia uncialis acetone extract.

(A) ${ }^{1} \mathrm{H}$ NMR $\left(700 \mathrm{MHz}\right.$, acetone- $\mathrm{d}_{6}$ ) of Cladonia uncialis crude extract and formulas of the two main components. (B) ${ }^{1} \mathrm{H} \mathrm{NMR}(700 \mathrm{MHz}$, acetone- $\mathrm{d}_{6}$ ) of Cladonia uncialis crude extract. (C) MS of Cladonia uncialis crude extract. Note: UA, usnic acid; SA, squamatic acid; (D) ${ }^{1} \mathrm{H}$ NMR (700 MHz) and MS data for Cladonia uncialis crude extract metabolites.

Table 1. Zone of growth inhibition for $(+)-,(-)$-usnic acids and the acetone extract of C. uncialis against bacteria and yeast-like fungi strains isolated from patients.

\begin{tabular}{|c|c|c|c|c|c|c|c|c|}
\hline \multirow{2}{*}{ Clinical strains } & \multicolumn{8}{|c|}{ Zone of growth inhibition $(\mathrm{mm})$} \\
\hline & $(+)-U A$ & $(-)-U A$ & CUE & $\mathrm{V}$ & $P$ & $\mathrm{AmC}$ & $E$ & $\mathrm{Cl}$ \\
\hline $\begin{array}{l}\text { Staphylococcus } \\
\text { aureus }\end{array}$ & 10 & 9 & 10 & 19 & 11 & 28 & 27 & 28 \\
\hline $\begin{array}{l}\text { Staphylococcus } \\
\text { epidermidis }\end{array}$ & 23 & 20 & 23 & 18 & - & 22 & 30 & 27 \\
\hline $\begin{array}{l}\text { Staphylococcus } \\
\text { haemolyticus }\end{array}$ & 22 & 12 & 22 & 17 & - & - & - & - \\
\hline $\begin{array}{l}\text { Enterococcus } \\
\text { faecalis }\end{array}$ & 21 & 15 & 21 & 17 & - & 28 & - & - \\
\hline $\begin{array}{l}\text { Enterococcus } \\
\text { faecium }\end{array}$ & 24 & 18 & 24 & 21 & - & - & - & - \\
\hline $\begin{array}{l}\text { Streptococcus } \\
\text { pyogenes }\end{array}$ & 9 & 12 & 12 & 18 & 28 & 34 & 23 & 20 \\
\hline $\begin{array}{l}\text { Escherichia } \\
\text { coli }\end{array}$ & - & - & - & - & - & - & - & - \\
\hline $\begin{array}{l}\text { Pseudomonas } \\
\text { aeruginosa }\end{array}$ & - & - & - & - & - & - & - & - \\
\hline $\begin{array}{l}\text { Candida } \\
\text { albicans }\end{array}$ & - & - & - & - & - & - & - & - \\
\hline $\begin{array}{l}\text { Candida } \\
\text { glabrata }\end{array}$ & - & - & - & - & - & - & - & - \\
\hline
\end{tabular}

Note: (+)-UA, (+)-Usnic acid $100 \mu \mathrm{g} /$ disc; (-)-UA, (-)-Usnic acid $100 \mu \mathrm{g} /$ disc; CUE, C. uncialis acetone extract - $100 \mu \mathrm{g} / \mathrm{disc}$; AmC, Amoxicillin/Clavulanic acid $30 \mu \mathrm{g} / \mathrm{disc} ; \mathrm{Cl}$, Clindamycin $2 \mu \mathrm{g} /$ disc; E, Erythromycin $15 \mu \mathrm{g} /$ disc; P, Penicillin $1 \mu \mathrm{g} /$ disc; V, Vancomycin $30 \mu \mathrm{g} /$ disc; ", ${ }^{\prime \prime}$ not active $=$ no inhibition zone $=$ disc diameter. The results were reported as the arithmetic mean obtained from 3 measurements. major differences between the tested substances were, observed. For S. pyogenes, GIZ for (+)-UA was the smallest.

It is widely known that therapeutic effect of chiral drugs may differ for the particular enantiomers (McConathy et al., 2003). Our results show that (+)-UA demonstrated the highest antibacterial activity against 5 out of 6 examined strains of Gram-positive bacteria, while (-)-UA acted more strongly only on $S$. pyogenes. The mechanism of antibacterial action of usnic acid was previously described. Namely, UA induces inhibition of RNA and DNA synthesis in Gram-positive bacteria (Bacillus subtilis and $S$. aureus), while in E. coli it does not inhibit production of any macromolecules (DNA, RNA, and proteins) (Maciag-Dorszyńska et al., 2014). This may explain the effect of the extract and usnic acid on the individual microbial strains involved in this study. Interestingly, our results showed that CUE, containing $52.52 \%$ of (-)-UA, demonstrated a higher activity in comparison to pure (-)-UA used at the same concentration. In our previous study, we observed that squamatic acid, 


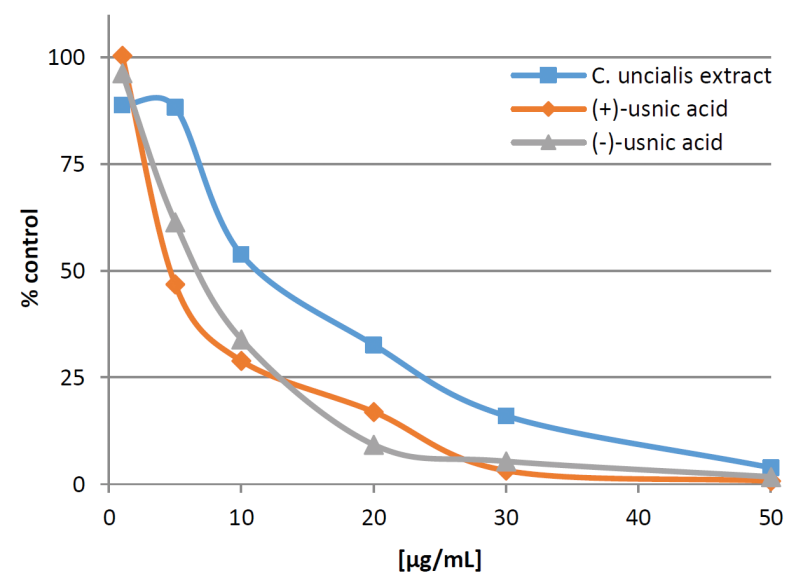

Figure 3. The effect of lichen-derived substances on the viability of $\mathrm{HaCaT}$ cells.

Mean values \pm S.E.M. obtained from three independent experiments are shown.

present in CUE, had no antibacterial effect against $S$. aureus (Studzińska-Sroka et al., 2015), while thamnolic acid, whose presence in this specie was described in the literature, demonstrated only a very weak activity: MIC 200$400 \mu \mathrm{g} / \mathrm{mL}$, for Gram-positive and Gram-negative bacteria, yeasts and filamentous fungi (Cankiliç et al., 2017). Based on the above, we suppose that the extract should contain low quantities of other, unidentified compounds that were responsible for its antibacterial activity and/

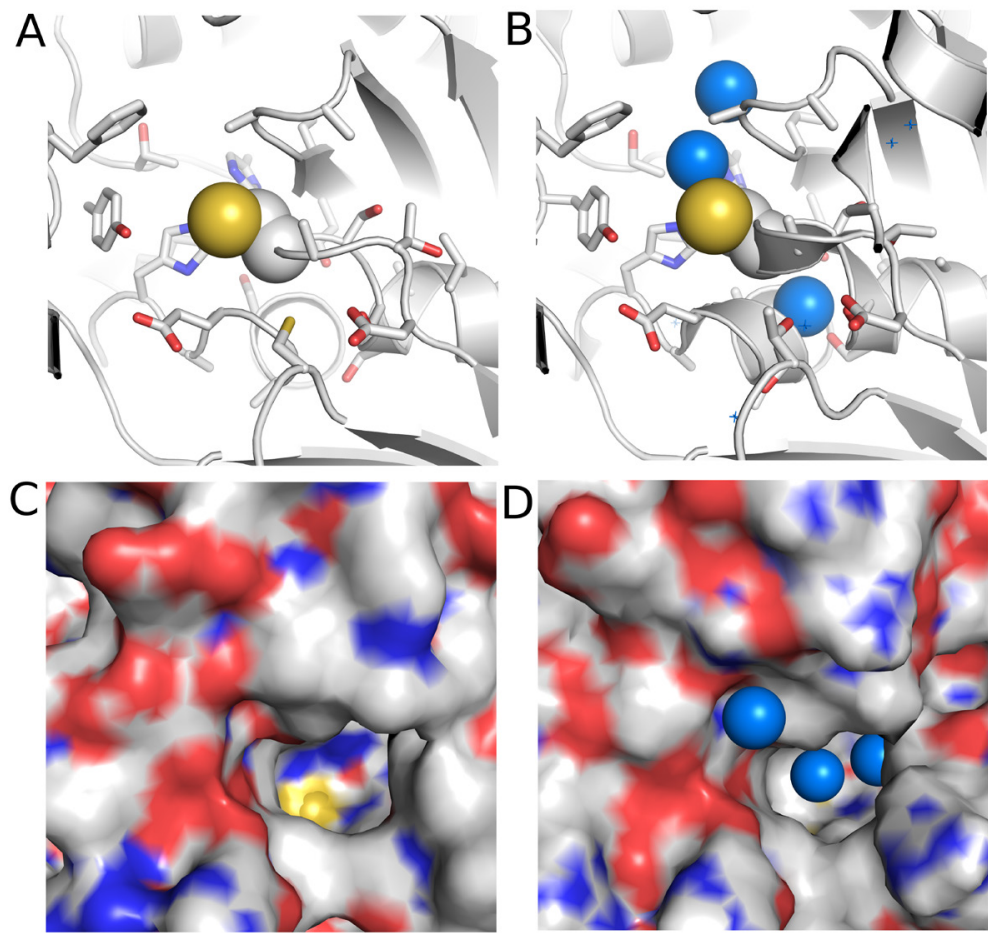

Figure 4. Comparison of C. uncialis ( $A$ and $C$ ) and $C$. nicotianae (B and D) active sites in KS domains.

Active site residues are shown with the ball and sticks representation, and Cys547 is depicted with the sphere representation. Water molecules present in the crystal structure of $C$. nicotianae polyketide synthase are shown as blue spheres when situated close to Cys547, and blue crosses when situated at a distance from this residue. There is an explicit water flow through the binding site tunnel in the $C$. nicotianae crystal structure of KS that could be produced, e.g., in the esterification reaction between the polyketide starter carboxyl group and SH of Cys547. The active site tunnel is similar in both homologous synthases, but Cys547 (yellow surface) is more visible in case of the $C$. uncialis synthase. or the specific synergism of its action. In this study, we observed a high effectiveness of CUE against Gram-posare known for their resistance to commonly used antiacterial drugs (Amyes et al., 2007; Fredheim et al., 2009). of antibacterial agents for antibiotic-resistant strains. Lack of the antifungal activity of the lichen exet al., 1999).

\section{Cell viability}

Keratinocytes (HaCaT) are a good in vitro model of epidermis. Other studies indicated that $(+)-\mathrm{UA}$ had a strong cytotoxic activity against keratinocytes $\left(\mathrm{EC}_{50}\right.$ $35 \mu \mathrm{M}$ and $75 \mu \mathrm{M}$, in crystal violet or neutral red uptake show that $(+)-\mathrm{UA}$ was more cytotoxic in comparison to UA and CUE (at a concentration of $5 \mu \mathrm{g} / \mathrm{mL}$, the viability of HaCaT cells was: $88.3 \%, 61.4 \%$, and $46.9 \%$ for CUE, (-)-UA and (+)-UA, respectively) and this effect among enantiomers of UA have been already described ine literature (Galanty et al., 2019), but numerous pose. Namely, it was shown that the cancer cells were breast cancer, Capan-2, breast adenocarcinoma) (Bazin et al., 2008; Einarsdóttir et al., 2010; Ebrahim et al., 2017), whereas (+)-UA was usually more toxic to V79, A549 (Koparal et al., 2006). Keratinocyte cells ( $\mathrm{HaCaT}$ ) were supposed to be a more standard biological system for testing CUE cytotoxicity but there has been no experimental data confirming this hypothesis and, to our knowledge, our study is the first one to demonstrate this. Our results indicate the safety of using CUE as an antibacterial agent and suggest that using it in antimicrobial ointments could be beneficial.

\section{Antioxidant activity}

So far, no studies have been published on the antioxidant activity of $C$. uncialis and (-)-UA. The results of our DPPH analysis showed that CUE, (-)-UA and $(+)-U A$ had low antioxidant activity $\left(\mathrm{IC}_{50}>200 \mu \mathrm{g} / \mathrm{mL}\right.$; at $200 \mu \mathrm{g} / \mathrm{mL}$ the ability to scavenge DPPH was $9.8 \%$, $13.2 \%$ and $14.0 \%$ for CUE, (-)-UA and $(+)-U A$, respectively). The observed low antioxidant activity of $(+)-\mathrm{UA}$ is consistent with previous data $\left(\mathrm{IC}_{50}=691 \mu \mathrm{g} /\right.$ $\mathrm{mL}$ ) described by Ananthi and others (Ananthi et al., 2015). Moreover, Brisdelli and others (Brisdelli et al., 2013) demonstrated that usnic acid at the concentration of $0.8 \mathrm{mM}$, did not show a significant ability to reduce concentration of the DPPH radical. Taking into account results of the above research, it can be assumed that the low antioxidant activity of CUE shown in our DPPH analysis, is probably due to a significant UA content. Despite the poor ability to scavenge the DPPH radical, UA displayed antioxi- 
dant properties in other research models (in vivo, in vitro). For example, UA isolated from Usnea longissima demonstrated an antioxidant effect and also increased the level of antioxidant enzymes in rats (Odabasoglu et al., 2006). Kohlhardt-Floehr and others (Kohlhardt-Floehr et al., 2010) had shown that under physiological conditions, low concentrations of UA extracted from Xanthoparmelia farinosa demonstrated antioxidant properties. Nevertheless, the above results suggest that the tested CUE may demonstrate antiradical properties.

\section{Molecular description of the KS domain of non- reducing polyketide synthase}

C. uncialis methylphloroacetophenone synthase (MPAS), like other polyketide synthases (PKS) (Herbst et al., 2018), is a microbial multidomain enzyme that catalyses polyketide biosynthesis in various species. The first step of polyketide synthesis involves loading/condensing a substrate onto an integral acyl carrier protein (ACP) and then transferring it to the ketosynthase (KS) domain interacting with the starter unit acyltransferase (SAT) and malonyl-CoAspecific acyltransferase (MAT) domains. Other domains of C. uncialis MPAS (Uniprot entry: A0A0R8YWJ7) include the methyltransferase (CMe'T) and Claisen cyclase (CLC) domains. Polyketide synthesis begins at the binding site of KS domain with a conserved Cys547 residue (see Fig. 4). The active site tunnel of C. uncialis KS is similar to the active site of Cercospora nicotianae $\mathrm{KS}$, for which the SATKS-MAT complex structure is available in PDB (Herbst et al., 2018). There is, however, a difference in one active site residue (Thr instead of Cys) that is close to the active site Cys547 (see Fig. 4). The first stage of the polyketide synthesis involves forming a thioester between the carboxyl group of the polyketide starter and $\mathrm{SH}$ of Cys547, and further elongation of the polyketide chain (MAT domain) and cyclization (CLC domain) (Herbst et al., 2018). The resulting intermediate product of MPAS is methylphloracetophenone that subsequently undergoes oxidative dimerization to usnic acid which is carried out by the methylphloracetophenone oxidase (MPAO) (AbdelHameed et al., 2016).

\section{CONCLUSIONS}

Based on the results of microbiological tests, the acetone extract from C. uncialis may be considered as a source of interesting lichen substance, helpful in treatment of skin infections caused by antibiotic-resistant bacterial strains. It should be emphasized that CUE is less toxic and at the same time its antibacterial activity is stronger than pure $(+)-U A$, used, e.g. as an antibacterial agent in topical formulations (Bruno et al., 2013; Francolini et al., 2018). The biosynthesis potential of $C$. uncialis and other lichens is still poorly explored due to the lack of any experimental evidence for definite linking biosynthetic gene clusters with secondary metabolites. Only recently, first attempts in the functional genome annotation have been carried out (Bertrand et al., 2018a; Calchera et al., 2019). Nevertheless, their importance as a natural source of polyketides from which a number of pharmacologically active substances is derived (Helfrich et al., 2014), would increase the intensity of ongoing research.

\section{Acknowledgments}

ESS would like to thank Prof. Wiesława Bylka for support in the experimental part of the research and for constructive suggestions during manuscript preparation.

\section{Conflicts of Interest}

The authors declare no conflict of interest.

\section{REFERENCES}

Abdel-Hameed M, Bertrand RL, Piercey-Normore MD, Sorensen JL (2016) Putative identification of the usnic acid biosynthetic gene cluster by de novo whole-genome sequencing of a lichen-forming fungus. Fungal Biol 120: 306-316. https://doi.org/10.1016/j.funbio.2015.10.009

Alahmadi AA (2017) Usnic acid biological activity: history, evaluation and usage. Int J Basic Clin Pharmacol. 6: 2752-2759. https://doi. org/10.18203/23192003.ijbcp20175072

Amyes SGB (2007) Enterococci and streptococci. Int I Antimicrob Agents 29: 43-52. https://doi.org/10.1016/S0924-8579(07)72177-5

Ananthi R, Tinabaye A, Selvaraj G (2015) Antioxidant study of usnic acid and its derivative usnic acid diacetate. IJRET 4: 356-366. https://doi.org/10.15623/ijret.2015.0402047

Annegowda HV, Anwar LN, Mordi MN, Ramanathan S, Mansor SM (2010) Influence of sonication on the phenolic content and antioxidant activity of Terminalia catappa L. leaves. Pharmacognosy Res 2: 368-373. https://doi.org/10.4103/0974-8490.75457

Bazin MA, Le Lamer AC, Delcros JG, Rouaud I, Uriac P, Boustie J, Corbel JC, Tomasi S (2008) Synthesis and cytotoxic activities of usnic acid derivatives. Bioorgan Med Chem 16: 6860-6866. https://doi. org/10.1016/j.bmc.2008.05.069

Bertrand RL, Abdel-Hameed M, Sorensen JL (2018a) Lichen biosynthetic gene clusters. Part I. Genome sequencing reveals a rich biosynthetic potential. J Nat Prod 81: 723-731. https://doi. org/10.1021/acs.jnatprod.7b00769

Bertrand R, Abdel-Hameed M, Sorensen JL (2018b) Lichen biosynthetic gene clusters. Part II. Homology mapping suggests a functional diversity. J Nat Prod 81: 732-748. https://doi.org/10.1021/ acs.jnatprod. $7 \mathrm{~b} 00770$

Bertrand RL, Sorensen JL (2019) Lost in translation: challenges with heterologous expression of lichen polyketide synthases. Chemistry Select 4: 6473-6483. https://doi.org/10.1002/slct.201901762

Bjerke JW, Elvebakk A, Dominiguez E, Dahlback A (2005) Seasonal trends in usnic acid concentrations of Arctic, alpine and Patagonian populations of the lichen Flavocetraria nivalis. Phytochemistry 66: 337-344. https://doi.org/10.1016/j.phytochem.2004.12.007

Brisdelli F, Perilli M, Sellitri D, Piovano M, Garbarino JA, Nicoletti M, Bozzi A, Amicosante G, Celenza G (2013) Cytotoxic activity and antioxidant capacity of purified lichen metabolites: an in vitro study. Phytother Res 27: 431-437. https://doi.org/10.1002/ptr.4739

Bruno M, Trucchi B, Burlando B, Ranzato E, Martinotti S, Akkol EK, Süntar I, Keleş H, Verotta L (2013) (+)-Usnic acid enamines with remarkable cicatrizing properties. Bioorg Med Chem 21: 1834-1843. https://doi.org/10.1016/j.bmc.2013.01.045

Burlando B, Ranzato E, Volante A, Appendino G, Pollastro F, Verotta L (2009) Antiproliferative effects on tumor cells and promotion of keratinocytes wound healing by different lichen compounds. Planta Med 75: 607-613. https://doi.org/10.1055/s-0029-1185329

Calchera A, Dal Grande F, Bode HB, Schmitt I (2019) Biosynthetic Gene Content of the 'Perfume Lichens' Evernia prunastri and Pseudevernia furfuracea. Molecules 24: 203. https://doi.org/10.3390/molecules 24010203

Cankilıç MY, Sarı̈̈zlü NY, Candan M, Tay F (2017) Screening of antibacterial, antituberculosis and antifungal effects of lichen Usnea florida and its thamnolic acid constituent. Biomed Res 28: 3108-3113

Candan M, Yilmaz M, Tay T, Erdem M, Türk AO (2007) Antimicrobial activity of extracts of the lichen Parmelia sulcata and its salazinic acid constituent. Z Naturforsch C 62: 619-621. https://doi. org/10.1515/znc-2007-7-827

Cetin H, Tufan O, Ozdemir TA, Tay T, Candan M, Yanikoğlu A, Sümbül H (2008) Insecticidal activity of major lichen compounds, $(-)$ and $(+)$ usnic acid, against the larvae of house mosquito, Culex pipiens L. Parasitol Res 102: 1277-1279. https://doi.org/10.1007/ s00436-008-0905-8

Cimmino A, Nimis PL, Masi M, De Gara L, van Otterlo WAL, Kiss R, Evidente A, Lefranc F (2019) Have lichenized fungi delivered promising anticancer small molecules. Phytochem Rev 18: 1-36. https://doi.org/10.1007/s11101-018-9577-x

Ebrahim HY, Akl MR, Elsayed HE, Hill RA, El Sayed KA (2017) Usnic acid benzylidene analogues as potent mechanistic target of rapamycin inhibitors for the control of breast malignancies. J Nat Prod 80: 932-952. https://doi.org/10.1021/acs.jnatprod.6b00917

Einarsdóttir E, Groeneweg J, Björnsdóttir GG, Harethardottir G, Omarsdóttir S, Ingólfsdóttir K, Ogmundsdóttir HM (2010) Cellular mechanisms of the anticancer effects of the lichen compound usnic acid. Planta Med 76: 969-974. https://doi. org/10.1055/s-0029-1240851 
Francolini I, Piozzi A, Donelli G (2018) Usnic acid: potential role in management of wound infections. Adv Exp Med Biol 1-11. https:// doi.org/10.1007/5584_2018_260

Fredheim EG, Klingenberg C, Rohde H, Frankenberger S, Gaustad P, Flaegstad T, Sollid JE (2009) Biofilm Formation by Staphylococcus haemolyticus. J Clin Microbiol 47: 1172-1180. https://doi:10.1128/ JCM.01891-08

Galanty A, Koczurkiewicz P, Burakowska D, Janeczko Z (2012) Biological and pharmacological activity of usnic acid. Post Fitoter 3: 162-172 (in Polish)

Galanty A, Paśko P, Podolak I (2019) Enantioselective activity of usnic acid: a comprehensive review and future perspectives. Phytochem Rev 18: 527-548. https://doi.org/10.1007/s11101-019-09605-3

Gawron-Gzella A, Witkowska-Banaszczak E, Bylka W, Dudek-Makuch M, Odwrot A, Skrodzka N (2016) Chemical composition, antioxidant and antimicrobial activities of Sanguisorba officinalis L. extracts. Pharm Chem J 50: 244-249. https://doi.org/10.1007/s11094-0161431-0

Grube M, Berg G, Andrésson ÓS, Vilhelmsson O, Dyer P S, Miao VPW (2014) In The Ecological Genomics of Fungi. Martin F eds, pp 191212. John Wiley \& Sons. https://doi.org/10.1002/9781118735893

Helfrich EJ, Reiter S, Piel J (2014) Recent advances in genome-based polyketide discovery. Curr Opin Biotechnol 29: 107-115. https://doi. org/10.1016/j.copbio.2014.03.004

Herbst DA, Huitt-Roehl CR, Jakob RP, Kravetz JM, Storm PA, Alley JR, Townsend CA, Maier T (2018) The structural organization of substrate loading in iterative polyketide synthases. Nat Chem Biol 14: 474-479. https://doi.org/10.1038/s41589-018-0026-3

Kohlhardt-Floehr C, Boehm F, Troppens S, Lademann J, Truscott TG (2010) Prooxidant and antioxidant behaviour of usnic acid from lichens under UVB-light irradiation-studies on human cells. J Photochem Photobiol B 101: 97-102. https://doi.org/10.1016/j.jphotobiol.2010.06.017

Koparal AT, Ayaz Tüylü B, Türk H (2006) In vitro cytotoxic activities of (+)-usnic acid and (-)-usnic acid on V79, A549, and human lymphocyte cells and their non-genotoxicity on human lymphocytes. Nat Prod Res 20: 1300-1307. https://doi. org/10.1080/14786410601101910

Latek D (2017) Rosetta Broker for membrane protein structure prediction: concentrative nucleoside transporter 3 and corticotropin-releasing factor receptor 1 test cases. BMC Struct Biol 17: 8. https://doi. org/10.1186/s12900-017-0078-8

Lücking R, Hodkinson BP, Leavitt SD (2016) The 2016 classification of lichenized fungi in the Ascomycota and Basidiomycota - ap- proaching one thousand genera. Bryologist 119: 361-416. https://doi. org/10.1639/0007-2745-119.4.361

Maciąg-Dorszyńska M, Węgrzyn G, Guzow-Krzemińska B (2014) Antibacterial activity of lichen secondary metabolite usnic acid is primarily caused by inhibition of RNA and DNA synthesis. FEMS Microbiol Lett 353: 57-62. https://doi.org/10.1111/1574-6968.12409

Madden TL, Tatusov RL, Zhang J (1996) Applications of network BLAST server. Methods Enzymol 266: 131-141. https://doi. org/10.1016/s0076-6879(96)66011-x

McConathy J, Owens MJ (2003) Stereochemistry in drug action. Prim care companion. J Clin Psychiatry 5: 70-73. https://doi.org/10.4088/ pcc.v05n0202

Millot M, Tomasi S, Articus, Rouaud I, Bernard A, Boustie J (2007) Metabolites from the lichen Ocbrolechia parella growing under two different heliotropic conditions. J Nat Prod 70: 316-318. https:// doi.org/10.1021/np060561p

Mitrović T, Stamenković S, Cvetković V, Tošić S, Stanković M, Radojević I, Stefanović, O, Comić L, Dačić D, Curčić M, Marković S (2011) Antioxidant, antimicrobial and antiproliferative activities of five lichen species. Int J Mol Sci 12: 5428-548. https://doi. org/10.3390/ijms12085428

Neupane BP, Malla KP, Gautam A, Chaudhary D, Paudel S, Timsina S, Jamarkattel N (2017) Elevational trends in usnic acid concentration of lichen Parmelia flexilis in relation to temperature and precipitation. Climate 5: 40. https://doi.org/10.3390/cli5020040

Odabasoglu F, Cakir A, Suleyman H, Aslan A, Bayir Y, Halici M, Kazaz C (2006) Gastroprotective and antioxidant effects of usnic acid on indomethacin-induced gastric ulcer in rats. J Ethnopharmacol 103: 59-65. https://doi.org/10.1016/j.jep.2005.06.043

Purvis OW, Coppins BJ, Hawksworth DL, James PW, Moore DM (1992) The lichen flora of Great Britain and Irleand. pp 204. Natural History.

Studzińska-Sroka E, Hołderna-Kędzia E, Galanty A, Bylka W, Kacprzak K, Ćwiklińska K (2015) In vitro antimicrobial activity of extracts and compounds isolated from Cladonia uncialis. Nat Prod Res 29: 2302-2307. https://doi.org/10.1080/14786419.2015.1005616

Webb B, Sali A (2016). Comparative Protein Structure Modeling Using MODELLER. Curr Protoc Bioinformatics 54: 5.6.1-5.6.37. https://doi. org $/ 10.1002 /$ cpbi.3

Wójciak H (2007) Lichens. In Lichens. In Lichens, bryophytes, ferns. Flora Polski. pp 90. Multico (in Polish)

Yang Y, Anderson EJ (1999) Antimicrobial activity of a porcine myeloperoxidase against plant pathogenic bacteria and fungi. J Appl Microbiol 86: 211-220. 